\begin{tabular}{|c|c|c|c|c|c|c|}
\hline \multirow{4}{*}{ Impact Factor: } & ISRA (India) & $=3.117$ & SIS (USA) & $=0.912$ & ICV (Poland) & $=6.630$ \\
\hline & ISI (Dubai, UAE & $=0.829$ & РИНЦ (Russia & $=0.156$ & PIF (India) & $=1.940$ \\
\hline & GIF (Australia) & $=0.564$ & ESJI (KZ) & $=8.716$ & IBI (India) & $=4.260$ \\
\hline & JIF & $=1.500$ & SJIF (Morocco & $=5.667$ & OAJI (USA) & $=0.350$ \\
\hline
\end{tabular}

\section{SOI: $1.1 /$ TAS DOI: $10.15863 /$ TAS International Scientific Journal Theoretical \& Applied Science}

p-ISSN: 2308-4944 (print) $\quad$ e-ISSN: 2409-0085 (online)

Year: 2019 Issue: $04 \quad$ Volume: 72

Published: $10.04 .2019 \quad$ http://T-Science.org

SECTION 31. Economic research, finance, innovation, risk management.

UDC 339.9.
QR - Issue

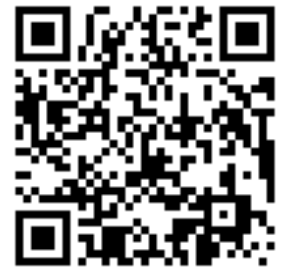

QR - Article

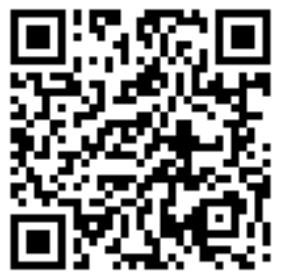

Konstantin Ivanovich Kurpayanidi

$\mathrm{Ph} \mathrm{D}$ in economics, professor of the Russian academy of natural sciences, Fergana polytechnic institute, Fergana, Uzbekistan Corresponding member of the International Academy of

Theoretical \& Applied Sciences https://orcid.org/0000-0001-8354-1512 w7777@mail.ru

\title{
ACTUAL ISSUES OF ACTIVATION OF FOREIGN ECONOMIC ACTIVITY IN THE ECONOMY OF UZBEKISTAN
}

Abstract: In the work, on the basis of the system analysis, some topical issues of activating the foreign economic activity of the economic entities of the Republic of Uzbekistan are considered. It is proved that an effective management mechanism in the sphere of foreign economic relations should be formed on the basis of an innovative approach. The intensification of foreign economic entrepreneurial initiatives and the influence of government bodies contribute to the improvement of the concept of state regulation of processes of foreign economic cooperation and the creation of foreign policy instruments of state government bodies in the post-crisis period. In accordance with the Action Strategy for the five priority directions of development of the Republic of Uzbekistan in 2017-2021, the strategy of innovative development is a necessary factor for the integration of Uzbekistan into the world community. The author offers a number of effective measures for the further expansion of foreign economic relations of the Republic of Uzbekistan in the context of global economic integration and the digital economy.

Key words: Foreign economic relations, foreign economic relations, foreign trade, innovations, management mechanism, digital economy, knowledge economy.

Language: English

Citation: Kurpayanidi, K. I. (2019). Actual issues of activation of foreign economic activity in the economy of Uzbekistan. ISJ Theoretical \& Applied Science, 04 (72), 60-65.

Soi: http://s-o-i.org/1.1/TAS-04-72-10 Doi: crossef https://dx.doi.org/10.15863/TAS.2019.04.72.10

\section{Introduction}

In the Republic of Uzbekistan for the years of independence a system of state regulation of foreign economic activity has been formed, which, as a complex system, depends on the effectiveness of a multi-level management mechanism, and its implementation is possible provided mutual adaptation of the instruments of foreign economic policy of enterprises and state structures. The activation of foreign economic entrepreneurial initiatives and the influence of management bodies contribute to the improvement of the concept of state regulation of foreign economic cooperation processes and the creation of a tool for foreign policy of state bodies in the post-crisis period.

In accordance with the Strategy of Action on the five priority development directions of the Republic of Uzbekistan in 2017-2021, the strategy of innovative development is an essential factor of Uzbekistan's integration into the world community. Innovative economy is, first of all, a flexible and dynamic economy in which new and disappearing companies are created and disappear, new markets are being searched for and new market niches are being developed [1].

An important incentive in this process can be foreign economic activity (FEA) and its key component - the export of goods of a high degree of processing. However, this requires the formation of a mechanism for managing the innovative development of Uzbekistan's foreign trade activities, industries and individual enterprises based on raising the level of management, modernizing production, and developing high-tech export industries. This is the 


\begin{tabular}{|c|c|c|c|c|c|c|}
\hline \multirow{4}{*}{ Impact Factor: } & ISRA (India) & $=3.117$ & SIS (USA) & $=0.912$ & ICV (Poland) & $=6.630$ \\
\hline & ISI (Dubai, UAE & $=0.829$ & РИНЦ (Russia) & $=0.156$ & PIF (India) & $=1.940$ \\
\hline & GIF (Australia) & $=0.564$ & ESJI (KZ) & $=8.716$ & IBI (India) & $=4.260$ \\
\hline & JIF & $=1.500$ & SJIF (Morocco & $=5.667$ & OAJI (USA) & $=0.350$ \\
\hline
\end{tabular}

reason for the policy pursued by the President of the country, Sh. Mirziyoyev, who in his message to Oliy Majlis notes: "We will resume negotiations on accession to the World Trade Organization. In order to further stimulate exports, it is necessary to bring the technical regulation system in line with international standards. One of our main tasks is to bring quality and certified products to the foreign market under the Uzbek brand" [2].

Based on the adopted laws and fundamental principles, an independent foreign economic policy was formed in Uzbekistan that meets the interests, the growth of authority and the country's position in the world community.

So, according to the State Statistics Committee, in January-December 2018, the republic's foreign trade turnover amounted to 33809.1 million USD, including exports - 14253.9 million USD, its structure has been qualitatively changed due to an increase in the share of finished products with high added value [3].

The main factor in accelerating structural reforms was the creation of a favorable investment climate in the republic. For example, in JanuaryDecember 2018, the development of the economy and social sphere of the Republic of Uzbekistan from the sources of financing mastered 107333.0 billion soums of investments in fixed assets (in dollars equivalent to 13.3 billion dollars), or $118.1 \%$ to the corresponding period of 2017. During the reporting period of 2018, a high level of investment activity was observed in the Republic of Uzbekistan with an increase of $18.1 \%$ compared with the previous year. In the dynamics of investment in fixed assets in 2005 amounted to $2.0 \mathrm{tln}$. soums, or increased by $12.0 \%, 2010-10.8$ trillion soums, or increased by $9.0 \%$, in 2015 they reached 28.5 trillion soums, or by $8.1 \%$.

The ratio of investments in fixed assets to GDP was $26.3 \%$, which is by 3.7 percentage points more than in comparison with the same period of 2017.

The volume of export services in JanuaryDecember 2018 amounted to 3029.9 million USD, or $21.3 \%$ of its total volume and increased, compared to the same period last year, by $22.4 \%$. As part of the export of services, the lion's share is taken up by transport services, tourism, as well as telecommunication, information, computer and financial services (Fig.1).

In the conditions of the world economic crisis, the important directions of the development of the national economy are innovative, investment and intellectual development. Along with this, the world economy is changing, in which turbulent processes of regional international integration and global liberalization are taking place. The foreign economic activity of states is also being modified, and consequently their role in managing and regulating foreign economic processes. Uzbekistan is included in the world economic processes under the influence of the external environment of already formed foreign economic relations.

\section{Literature review}

Among foreign studies, in the field of regulation of foreign economic activity, it is possible to mention the works of M. Alle [4], J. Keynes [5], P. Krugman [6], A. Marshall [7] and scientists of Uzbekistan A.Vahobov [8], A. Rasulev [9], E. Trushin [10], B. Khodiev [11] and others.

For the theoretical comprehension and deepening of the problem of state regulation of foreign economic policy, the works of B. Balassa [12], J. Bhagwati [13], R. Jones [14], R. Samuelson [15], J. Stiglitz [16] and others are of great importance.

At the same time, there is still a significant gap between the theory and practice of regulation of foreign economic activity on the basis of innovative development of the national economy. Immunity to innovations, separation from world trends in scientific and technological development can lead to socioeconomic and structural and technological backwardness. The fundamentals of the organizational and economic mechanism of scientific and innovation policy have not been fully developed yet, the responses of the branch management bodies to the challenges of the modern economy that require increasing the efficiency of innovation development are inadequate.

There remain a number of insufficiently developed questions connected with the definition of the place and role of state regulation of foreign economic operations in the management system of the modern market economy. A detailed analysis of factors affecting the management of local, regional and international liberalization of foreign economic relations is required. Meanwhile, the implementation of the goals of foreign economic activity in the context of globalization presupposes a strategic level of management of activities, including, among other things, decisions related to determining the opportunities and forms of entering foreign markets, selecting target segments, ways of penetrating them, understanding the requirements of consumers in other countries, etc. All of the above and predetermined the choice of the topic of this study. 


\begin{tabular}{|c|c|c|c|c|c|c|}
\hline \multirow{4}{*}{ Impact Factor: } & ISRA (India) & $=3.117$ & SIS (USA) & $=0.912$ & ICV (Poland) & $=6.630$ \\
\hline & ISI (Dubai, UAE & $=0.829$ & РИНЦ (Russia & $=\mathbf{0 . 1 5 6}$ & PIF (India) & $=1.940$ \\
\hline & GIF (Australia) & $=0.564$ & ESJI (KZ) & $=8.716$ & IBI (India) & $=4.260$ \\
\hline & JIF & $=1.500$ & SJIF (Morocco & $=5.667$ & OAJI (USA) & $=0.350$ \\
\hline
\end{tabular}

\section{Share of seven major partner countries in the export of goods and services}

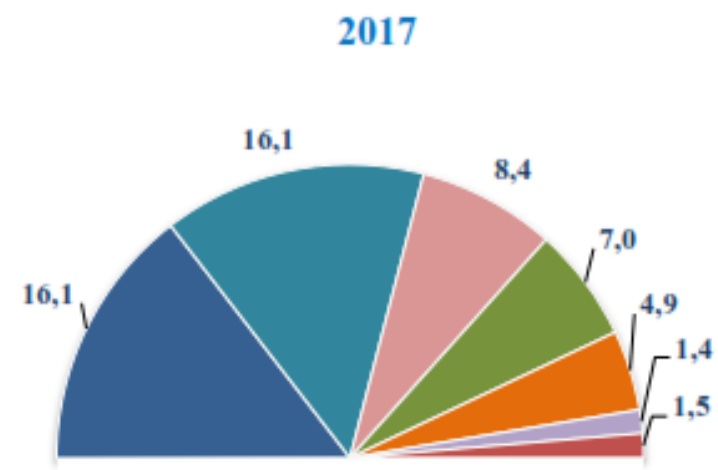
January-December
2018
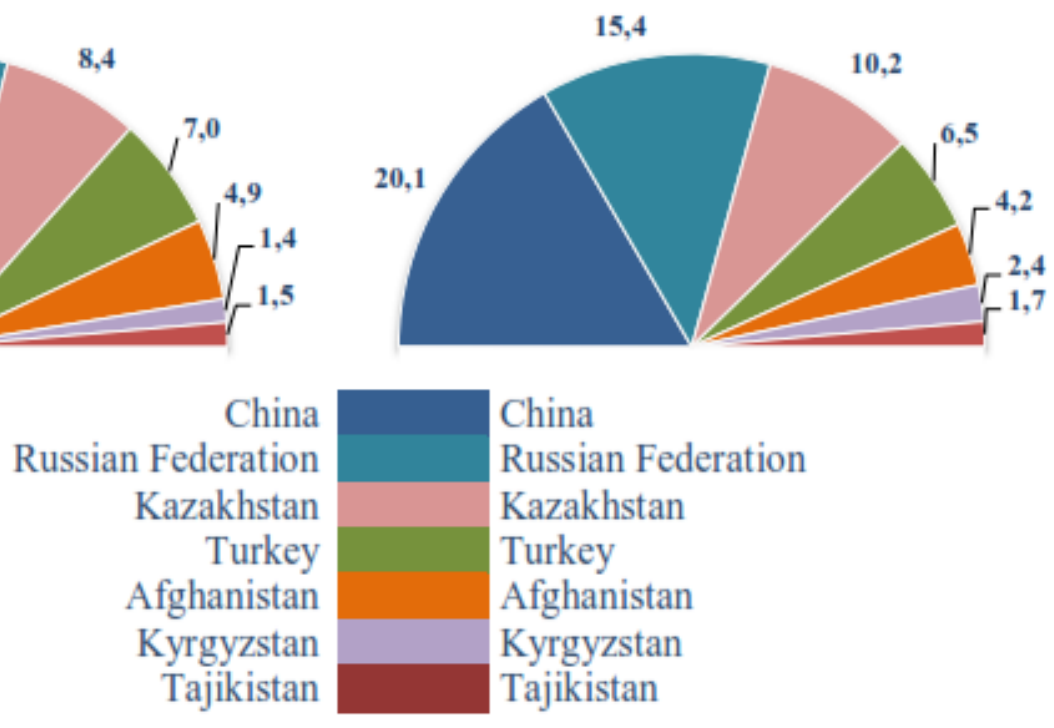

China

Russian Federation

Kazakhstan

Turkey

Afghanistan

Kyrgyzstan

Tajikistan

Fig. 1. Share of seven major partner countries in the export a goods and services

\section{Literature review}

Among foreign studies, in the field of regulation of foreign economic activity, it is possible to mention the works of M. Alle [4], J. Keynes [5], P. Krugman [6], A. Marshall [7] and scientists of Uzbekistan A.Vahobov [8], A. Rasulev [9], D. Trostyanskiy [10], B. Khodiev [11] and others.

For the theoretical comprehension and deepening of the problem of state regulation of foreign economic policy, the works of B. Balassa [12], J. Bhagwati [13], R. Jones [14], R. Samuelson [15], J. Stiglitz [16] and others are of great importance.

At the same time, there is still a significant gap between the theory and practice of regulation of foreign economic activity on the basis of innovative development of the national economy. Immunity to innovations, separation from world trends in scientific and technological development can lead to socioeconomic and structural and technological backwardness. The fundamentals of the organizational and economic mechanism of scientific and innovation policy have not been fully developed yet, the responses of the branch management bodies to the challenges of the modern economy that require increasing the efficiency of innovation development are inadequate.

There remain a number of insufficiently developed questions connected with the definition of the place and role of state regulation of foreign economic operations in the management system of the modern market economy. A detailed analysis of factors affecting the management of local, regional and international liberalization of foreign economic relations is required. Meanwhile, the implementation of the goals of foreign economic activity in the context of globalization presupposes a strategic level of management of activities, including, among other things, decisions related to determining the opportunities and forms of entering foreign markets, selecting target segments, ways of penetrating them, understanding the requirements of consumers in other countries, etc. All of the above and predetermined the choice of the topic of this study.

\section{Methods of research.}

The basis of theoretical development of the problem posed and the solution of problems are general scientific methods: systematic, systemfunctional, comparative, econometric and economicstatistical analyzes, as well as approaches involving the study of the problem at the micro- and macro level, the use of forecast and rating estimates

\section{Analysis and results}

In modern conditions, a new model of economic development of states is forming, the most important feature of which has been the activation of innovative processes. In this regard, the formation of the national 


\begin{tabular}{|c|c|c|c|c|c|c|}
\hline \multirow{4}{*}{ Impact Factor: } & ISRA (India) & $=3.117$ & SIS (USA) & $=0.912$ & ICV (Poland) & $=6.630$ \\
\hline & ISI (Dubai, UAE & $=0.829$ & РИНЦ (Russia & $=0.156$ & PIF (India) & $=1.940$ \\
\hline & GIF (Australia) & $=0.564$ & ESJI (KZ) & $=8.716$ & IBI (India) & $=4.260$ \\
\hline & JIF & $=1.500$ & SJIF (Morocco & $=5.667$ & OAJI (USA) & $=0.350$ \\
\hline
\end{tabular}

innovation system in Uzbekistan is a key task not only for the scientific and technical sphere, but also for increasing the competitiveness of the domestic economy.

As an element of the system of state regulation, the program of innovative development of the economy should have:

- clearly defined goals;

- management bodies and implementing functions capable of ensuring the achievement of the formulated goals;

- system that forms an information image of the regulatory object, sufficient for the implementation of management functions;

- regulation and support instruments, through which the government bodies influence the enterprises and the environment in the performance of their functions.

Effective use of the available scientific and technical potential is possible only with the help of a consistent and steadily carried out scientific and technical policy, corresponding to the real socioeconomic conditions of the republic and aimed at addressing the pressing problems of its development. Innovative technological development requires very considerable financial resources and a certain time. In this respect, priorities are given to the accelerated development of those sectors of the economy where there are traditional advantages in international trade. These are labor-intensive and resource-intensive industries for the production and advanced processing of agricultural and mineral raw materials. The implementation of innovative development envisages a purposeful industrial policy applied to each individual industry. When solving the problem of the effectiveness of scientific and technical potential, the concentration of forces and resources in the direction of intensifying work in the development of highly effective scientific and technical products in all stages of the chain, from the generation of ideas, their prototype, to their introduction into production and to obtain a certain economic effect.

In order to further develop innovation as a priority area of the national economy, it is advisable to change economic policy in the direction of building up national competitive advantages on the main lines of formation of a new technological order and concentration of financial, information and intellectual resources available in the country.

The most effective form of foreign participation in the scientific and technical sphere is the creation of joint innovation structures, although it is advisable to use other forms of participation, for example, foreign loans and loans.

In our opinion, the strengthening of the innovative orientation of investment policy and its activation presuppose the solution of a number of urgent tasks, namely:

- improvement of innovative and motivational mechanisms for the implementation of scientific and technical programs with the full economic support of the activity of invention and innovation;

- the formation of a modern system "scienceproduction", providing for a significant change in the structure of investment of its individual subsystems (research, design, development and testing of prototypes, their introduction and development in production);

- increase in the share of investments directed to the development of fundamental research in the field of foreign trade;

- the entry to the forefront of economic growth is possible only with the active interaction of investment and innovation complexes.

Based on these positions, the formation of investment and innovation markets, as well as the creation of mechanisms for their interaction, has now become a reality. The most important elements of the investment-innovative mechanism are the provision of resources for programs and projects, including material, technical, financial and personnel; transition to an innovative type of economy implies a change in its entire organization, as well as a qualitative improvement of the mechanism for managing scientific and technological development (Fig. 2.).

Studies have shown that one of the crucial conditions for stable innovative development for the future is the early identification of the need, development and creation of new technologies adapted to the predicted changes in sources of raw materials, energy, etc.

In practice, the degree of use of programtargeted methods for managing scientific and technological development is comparatively small because of the need to adapt known methods and models to the features of specific objects, as well as the creation of mandatory organizational-eq onomical conditions for the formation of a mechanism for managing scientific and technological development as an innovative form. 


\begin{tabular}{|c|c|c|c|c|c|c|}
\hline \multirow{4}{*}{ Impact Factor: } & ISRA (India) & $=3.117$ & SIS (USA) & $=0.912$ & ICV (Poland) & $=6.630$ \\
\hline & ISI (Dubai, UAE & $=0.829$ & РИНЦ (Russia & $=\mathbf{0 . 1 5 6}$ & PIF (India) & $=1.940$ \\
\hline & GIF (Australia) & $=0.564$ & ESJI (KZ) & $=8.716$ & IBI (India) & $=4.260$ \\
\hline & JIF & $=1.500$ & SJIF (Morocco & $=5.667$ & OAJI (USA) & $=0.350$ \\
\hline
\end{tabular}

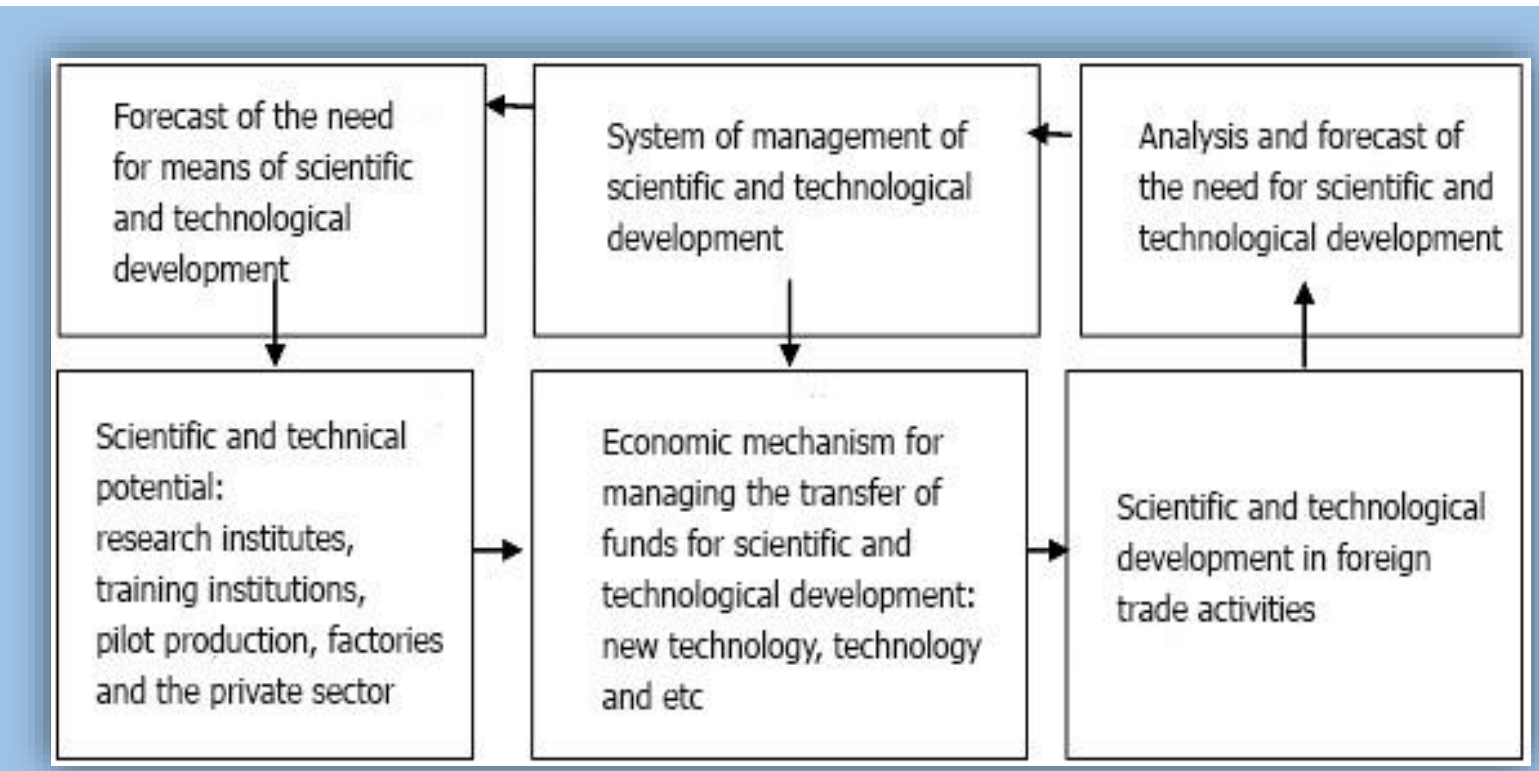

Fig. 2. Mechanism of management of scientific and technological development of FEA

Further improvement of ideas and tools of program-target management can become a basis for the formation of a new management mechanism. The formulation and practical solution of the long-term tasks of developing foreign economic activity on the basis of an innovative approach will ensure the achievement of effective results.

\section{Discussion of research results}

Improving the quality of the development of the strategy of scientific and technological development of foreign economic activity, based on the improvement of state innovation policy, significantly affects the economic performance of all industries that ensure a qualitative growth in exports of national products. Innovative policies oriented specifically on scientific and technological development will contribute to technological changes in all areas of foreign economic activity. In modern conditions, scientific research affects the progress of technology and the organization of production by improving the means of labor including technology, machinery, production facilities, etc. [17].

The most important areas of innovative development of foreign economic activity are:

- scientific and technological, since the progress of social production is a consequence of the progress of technology and technology in the aggregate of the means of labor created by people, and the progress of social production is a consequence of the progress of technology and technology in combination with the quality of the labor employed;

- development and liberalization of the economy aimed at further strengthening macroeconomic stability and maintaining high economic growth rates, increasing its competitiveness, modernizing and intensively developing agriculture, continuing institutional and structural reforms to reduce the state's presence in the economy, further strengthening the protection of rights and the priority role of private property, stimulating the development of small business and private entrepreneurship, an integrated and balanced social Economic and economic development of regions, regions and cities, the active attraction of foreign investment in the economy and regions of the country by improving the investment climate.

\section{Conclusions and suggestions}

An important mechanism for effective state innovation policy in foreign economic activity should be the selection, preparation and financing of the most important innovative projects of national importance. This will contribute to the adoption of effective managerial decisions, taking into account the priority areas for the development of science, technology and technology in the medium term [18].

The most important direction in the modern development of globalization is the formation of international innovation networks, joint scientific and technical creativity of different countries and their corporations in the interests not only of business, but also of the economic and scientific and technological development of the world economy [19]. In this regard, at present, the Republic faces the task of accelerating scientific and technological progress, shifting its industrial production to an innovative development path based on the software-based formation of an intellectual economy based on knowledge (knowledge-based economy), expanding scientific and technical ties and partnership with world scientific and technological leaders [20].

Given the continuing decentralization and liberalization of foreign trade activities, the previously 


\begin{tabular}{|c|c|c|c|c|c|c|}
\hline \multirow{4}{*}{ Impact Factor: } & ISRA (India) & $=3.117$ & SIS (USA) & $=0.912$ & ICV (Poland) & $=6.630$ \\
\hline & ISI (Dubai, UAE & $=0.829$ & РИНЦ (Russia & $=0.156$ & PIF (India) & $=1.940$ \\
\hline & GIF (Australia) & $=0.564$ & ESJI (KZ) & $=8.716$ & IBI (India) & $=4.260$ \\
\hline & JIF & $=1.500$ & SJIF (Morocco & $=\mathbf{5 . 6 6 7}$ & OAJI (USA) & $=0.350$ \\
\hline
\end{tabular}

functioning mechanisms for its regulation (licensing, quoting, etc.) are becoming ineffective. At the same time, solving problems on optimizing the external economic complex and using its capabilities to accelerate the processes of reconstruction and development of the country's production potential requires strengthening coordination of the activities of the subjects of foreign economic activity on the basis of effective implementation of its priorities.
In order to modernize the foreign economic complex, it is necessary to adopt fundamental laws, for example, such as the Law on Innovations and Modernization of the Economy, the Law on Competition, etc. It seems to us that improving the management of the wind farm in Uzbekistan on an innovative basis will further deepen democratic market reforms and liberalization of the economy.

\section{References:}

1. (2017). Strategy of actions on five priority directions of development of the Republic of Uzbekistan in 2017-2021. Decree of the President of the Republic of Uzbekistan of February 7, 2017 № DP-4947. Collected Legislation of the Republic of Uzbekistan, 2017, № 6 .

2. Mirziyoyev, S. M. (2017, December 23). Message of the President of the Republic of Uzbekistan to the Oliy Majlis. Narodnoye slovo.

3. (2019). Social and economic situation of the Republic of Uzbekistan in 2018. Tashkent.

4. Alle, M. (2003). Globalization: the destruction of employment and economic growth. Empirical Evidence. Moscow, Russia.

5. Keynes, J. M. (2018). The General Theory of the Rate of Interest. In The General Theory of Employment, Interest, and Money (pp.145-153).

6. Krugman, P., Obstfeld, M., \& Melitz, M. (2017). International Economics: Theory and Policy, the latest edition. Addison-Wesley.

7. Marshall, A. (2009). Principles of economics: unabridged eighth edition. Cosimo, Inc.

8. Vakhobov, A.V.(2015). World Economy and International Economic Relations. T.: SHARK.

9. Rasulev, A., Pavlov, K., \& Asadullina, N. (2013). Spetsifika sovremennogo etapa razvitiya mirovoy ekonomiki. Stabil'nost' i perspektivy ekonomiki Uzbekistana. Obshchestvo $i$ ekonomika, (4), 37-60.

10. Trostyanskiy, D., \& Rasulev, A. (2007). Institutsional'nyye preobrazovaniya na etape modernizatsii ekonomiki Uzbekistana. Vestnik Instituta ekonomiki RAN, (1).

11. Khodiev, B. Y. (2000). Export-oriented development of the economy of the Republic of Uzbekistan. Russian Entrepreneurship. №. 6.
12. Balassa, B. (1985). Exports, policy choices, and economic growth in developing countries after the 1973 oil shock. Journal of development economics, 18(1), 23-35.

13. Bhagwati, J. (1998). The capital myth: the difference between trade in widgets and dollars. Foreign Affairs, 7-12.

14. Jones, R. W., \& Kierzkowski, H. (2018). The role of services in production and international trade: A theoretical framework. World Scientific Book Chapters, 233-253.

15. Samuelson, P. A. (1948). International trade and the equalisation of factor prices. The Economic Journal, 58(230), 163-184.

16. Stiglitz, J. E. (2002). Towards a new paradigm for development: strategies, policies and processes.

17. Kurpayanidi, K. I, \& Abdullaev, A. M. (2018). Activation of FER on the basis of innovative development. Monograph. Germany, Lap Lambert Academic Publishing, 160.

18. Melnikas, B. (2008). The knowledge-based economy in the European Union: Innovations, networking and transformation strategies. Transformations in Business \& Economics, 7.

19. Malhotra, Y. (2002). Knowledge assets in the global economy: assessment of national intellectual capital. In Intelligent Support Systems: Knowledge Management (pp. 22-42). IGI Global.

20. Margianti, E. S., Ikramov, M. A., Abdullaev, A. M., Kurpayanidi, K. I., \& Ashurov, M. S. (2014). Systematical analysis of the position and further development of Uzbekistan national industry in the case of economic modernization. Monograph. Indonesia, Jakarta, Gunadarma Publisher. 